KAMILA BARANIECKA-OLSZEWSKA

Institute of Archaeology and Ethnology, Polish Academy of Sciences, Warsaw

\title{
THE STATE HISTORICAL POLICY AND THE DEFAULT RELIGIOUS HERITAGE IN POLAND: ON INTRODUCING PAGAN HERITAGE TO THE PUBLIC SPHERE IN KRAKÓW
}

\author{
THE MEMORY COMPLEX IN POLAND - \\ A FRAMEWORK FOR CONSIDERATIONS ON NATIONAL HERITAGE
}

The main premise of this article ${ }^{1}$ is that heritage-making involves religion and that nation-states refer to religious heritage when building projects of national identity (Astor, Burchardt, Griera 2017). Furthermore, religious heritage is shaped and used by politicians and culture participants to legitimize their agendas (De Cesari 2013). These processes take place on the state - mainly Roman Catholic - level as well as lower down - not only Catholic, forming a complicated, dynamic amalgam of identities, visions of history, and religions. To discern this entanglement, it is necessary to look at the relation between heritage and religion from two perspectives. This article is therefore divided into two main parts. The first describes the ties between historical policy, the memory complex, the construction of national heritage, and Roman Catholicism in Poland. The second focuses on the connections between heritage and religion, as exemplified in the organization of the Rękawka event in Kraków - a historical reenactment of early medieval Slavic rites (see Baraniecka-Olszewska 2016). I focus on this particular ethnographic fieldwork case in order to present grassroots attempts to introduce Pagan heritage to the public sphere.

Heritage and religion are visibly intertwined in social practice. Many places of religious cult have the status of heritage sites, while many rituals are regarded as the cultural heritage of particular groups. Scholars have recently analyzed the relations between the two phenomena from different perspectives, such as creating identity through the heritagization of local cults (Isnart 2008), transforming religious buildings into heritage (Coleman, Bowman 2018), or conflicts arising from the process of the heritagization of religious spaces (Di Giovine 2015). Such approaches investigate particular cases with regard to their changes in situ, offering insights into specific instances

1 This research was funded by the HERILIGION project "Heritagization of Religion and the Sacralization of Heritage in Contemporary Europe", HERA.15.033. The project is financially supported by the HERA, NCN, AHRC, FCT, DASTI, NWO, and the European Commission through Horizon 2020 under grant agreement No. 649307. The project's Polish section is based at the Institute of Ethnology and Cultural Anthropology, Faculty of History, Jagiellonian University in Kraków. 
of the relations between religion and heritage. Researchers have also attempted to grasp the more general mechanisms underlying the processes of transforming religion into national heritage, focusing on state policies toward particular religions (Astor, Burchard, Griera 2017). My aim is to combine these two perspectives in this article and by starting with an analysis of the current state policy toward religion, history, and heritage in Poland to provide a framework for the interpretation of a particular case study.

Heritage has become a way of thinking about history - of using and transforming it in contemporary societies (Tunbridge, Ashworth 1996). Along with collective memory, historical policies, and cultural representations of the past, heritage is a part of the phenomenon Sharon McDonald named "memoryland" or, less poetically, the "memory complex" (2013). She indicates that various types of historical representations and constructs of the past or of history-reliant forms are interwoven with each other. At the level of social and cultural practice, these performative intersections become what she calls the memory complex (McDonald 2013, p. 5). Adopting this term, I investigate the limits of the mutual influence of the top-down and bottom-up discourses within the memory complex. Although visions and constructs of heritage, collective memory, and historical policy are intrinsically connected, state policies and grassroots ideas about them often diverge. In a situation where history is democratized (de Groot 2008; Samuel 2012) and there is an increasing participation of non-academics or even non-professionals in creating visions and representations of the past in the contemporary social space, analyses of the relations between topdown and bottom-up initiatives are essential for the understanding of the constant transformations of the memory complex.

Although this article focuses on one particular case study, it tackles the crucial mechanisms of imposing a state-created vision of the national past on local activists and also their reactions to it - both positive and critical. The example analyzed - the organization of the Traditional Celebration of Rękawka (Tradycyjne Święto Rękawki) - provides an opportunity to examine whether the state-imposed historical policy is accepted or rejected in social practice, as well to ascertain the role of a minority religion in the process of constructing the project of national heritage.

\section{THE STATE AND RELIGION IN POLAND}

No analysis of the relations between the state policy, religion, national identity, and cultural heritage in Poland would be complete without taking into consideration the country's specific situation. The definite majority of its inhabitants are ethnic Poles: 94.83\% (Narodowy Spis Powszechny Ludności i Mieszkań 2011, p. 29)², and 92\% declare themselves to be Roman Catholic (CBOS Komunikat $z$ badan 2018) . $^{3}$ These facts give a very specific context for research on the relations between Polish

${ }^{2}$ https://stat.gov.pl/download/cps/rde/xbcr/gus/lud_raport_z_wynikow_NSP2011.pdf, access date 27.03.20019.

${ }^{3}$ https://www.cbos.pl/SPISKOM.POL/2018/K_147_18.PDF, access date: 18.03.20019. 
identity and Roman Catholicism, and situate all alternative - in this case, non-Roman Catholic - visions of national religious heritage in a minority position.

And even though the Constitution of the Republic of Poland of $1997^{4}$ guarantees equality and also freedom of faith to all citizens, the document itself emphasizes the strong affiliation between the Polish nation, its history, and Christianity ${ }^{5}$. Therefore, it suggests an official interpretation of the Polish past as Roman Catholic, a fact particularly visible in the Preamble to the Constitution.

The drafting of the preamble crystallized and intensified questions and debates that have been central in post-Communist Poland: questions of identity and collective memory, the meaning of recent history within broader modern Polish history, and the "historical" place of the Roman Catholic Church and its new role in post-Communist Poland (Zubrzycki 2006, p. 86).

Importantly, Christianity is not only present in state policies ${ }^{6}$ in Poland but also sets the standards of what is "traditional" and "normal" (Pasieka 2015, p. 55).

\section{As Geneviève Zubrzycki expresses it,}

I argue that there exists in Poland a triangular relationship between the form of the state, the definition of national identity, and the place and role of religion and the Catholic Church in society (2006, p. 22).

Further, she adds that:

The mobilizing discourse of the nation is primarily defined in ethno-religious terms, and the Roman Catholic Church is represented as the legitimate guardian and carrier of national values, providing institutional, ideological, and symbolic support to civil society (Zubrzycki 2006, p. 23).

Significantly, this close relation between Roman Catholicism and the nation-state in Poland has persisted for some time now (see Porter-Szücs 2011) and, on various levels, defines the lives not only of citizens identifying with Roman Catholicism, but also of those who do not acknowledge this kind of identity.

As Agnieszka Pasieka notices,

The normativity of the idea of the Pole-Catholic, which constitutes the foundation of hierarchical pluralism, may also translate into a "hierarchy of memories" and a "hierarchy of histories", making some memories and histories more appropriate and acceptable than others (2015, pp. 115-116).

Pasieka devotes her study to the coexistence of various religions and multiple "memories" and "histories" in one place, but encourages continued research on hierarchical pluralism: "in short, hierarchical pluralism is not limited to the few multireligious and multiethnic areas in Poland, but can be observed in many other dimensions of social and political life" (Pasieka 2015, p. 217). I consider this notion to be particularly applicable in studies on cultural heritage in Poland in order to

${ }^{4}$ http://www.sejm.gov.pl/prawo/konst/angielski/kon1.htm, accessed 26.03.2019.

${ }_{5}^{5}$ In the Polish political discourse Christianity is reduced to Roman Catholicism.

${ }^{6}$ Moreover, in 1993 the Holy See and Poland signed a Concordate (the agreement came into force in 1998) which granted the Roman Catholic Church a formally privileged position among other religions (see Pasieka 2015, p. 55). 
discern the access of particular denominations to public resources. The case of the Rękawka celebration and other attempts to introduce Pagan heritage to the public sphere demonstrate that in the dominant, state-supported Christian vision of the Polish past Pagan "histories" are marginalized and placed lower in the hierarchy of religious heritages. Thus Roman Catholic heritage has become a default element of national heritage in Poland.

\section{State policy on Poland's past}

It is a truism to say that while heritage remains a transnational notion, it is deeply dependent on nation-state policy (see Astor, Burchardt, Griera 2017; De Cesari 2013). Thus the general vision of national heritage is top-down, and as such it hardly appears as a participatory and democratic domain (see De Cesari 2013). Moreover, national heritage should be perceived as thoroughly discursive - not only as a notion created in discursive practices, but above all in the Foucauldian understanding of discursiveness, as producing power and knowledge and thus shaping practices concerning heritage-making (see Smith 2006). Another crucial fact for my further reflections is that the national heritage project in Poland embraces religious heritage, since it refers directly to Roman Catholic values. Just as Polish national identity projects are connected to Roman Catholicism (see Kubik 1994; Porter-Szücs 2011; Zubrzycki 2006), so too are national heritage and its related discursive practices. In this respect, the state vision of national heritage is coherent with the present state historical policy. Contemporary state historical policy is a project adopted more than a decade ago, by Polish right-wing politicians from the Law and Justice (Prawo i Sprawiedliwość) party, which has governed Poland since 2015 (see Traba 2010). One of the main objectives of the policy is to break with interpretations of history and national identity born during the period of Communist government in Poland. Along with the intensity and omnipresence of the policy in the public sphere, the general impression is that this is a brand new attitude toward history, yet the historical-policy ideologists refer to seemingly timeless projects of Polish history and identity deeply rooted in Christian values (see Łuczewski 2017).

The idea of Poland as a homogeneous Catholic nation, then, is simultaneously a claim about Poland's past and a demand that a particular model of national Catholicism be maintained in the present (Porter-Szücs 2011, p. 21).

\section{As Agnieszka Pasieka observes,}

[...] many different factors - above all, the realization of state policies - lead to a narrowing of [religious - K.B.-O.] pluralism, and the promotion of the Polish-Catholic connection to the exclusion of both religious and national "others". Present-day historiography too plays a role in this process (Pasieka 2015, p. 56).

7 The term "historical policy" (polityka historyczna) is quite new in public discourse in Poland. It was adopted in the Polish language at the beginning of the 2000s. It generally refers to the phenomena described in the German language as Geschichtspolitik or Erinnerungspolitik (see Korzeniewski 2008; Łuczewski 2017; Wolff-Powęska 2007). 
The default presence of Roman Catholicism in the state historical policy and in Polish historiography as the culture- and value-making factor puts "the others" - the followers of other religions and also people acknowledging the existence or heritages of other religions - in a difficult position. The situation is even more complicated when we speak of heterogeneous religions with a small number of believers, as is the case with Paganism. In Poland, the term Pagan is used to describe many different groups, with different formal statuses. There are Wiccans or Druids, and also groups of socalled ethnic Pagans invoking Celtic or Viking beliefs. The ethnic Pagan category also includes Native Faith believers (Rodzimowiercy), who are a large group of the Pagans in Poland. There is, however, no single church of the Native Faith (officially, there are several), and not all Native Faith believers are affiliated with any of them.

In this article I focus on so-called ethnic Paganism, here represented mostly by Rodzimowiercy, in which nativeness plays a significant role (see Simpson 2017). Paganism's reverence for local spirits, and a certain connection between believers and their ancestors and also with the land they inhabited, means that Paganism also offers projects of national identity based on the relation to a place and through these roots connecting contemporary believers to all the generations of their ancestors. Although the project of national identity, exactly like Paganism itself, is heterogeneous and embraces a wide range of attitudes, including nationalistic and racist conceptions of the national ideology (see Gajda 2009), it has created an alternative (to the Christian-biased) project of Polish national ideology (see Górewicz 2009). Along with an understanding of the origins of Polishness, the "Pagan" project offers a different interpretation of the Polish past. In this perspective the culture- and value-making factor is the Paganism originating in the region of Poland, in contrast to Christianity, which is perceived as foreign and imposed. Moreover, Pagans feel repressed by the omnipresence of Roman Catholicism (see Filip 2011; Simpson 2017). This feeling is often shared by people (e.g., early medieval historical reenactors) who, though they do not declare themselves Pagans, appreciate Paganism's role in Polish culture.

In the public discourse the debate on Poland's pre-Christian origins is rather marginal. Moreover, school textbooks or museums presenting Poland's beginnings set the starting point of Polish history at the moment when Mieszko I, a ruler uniting various Slavic groups, accepted Christianity. The past before the so-called Baptism of Poland is presented as barbaric and legendary. Pre-Christian times thus seem ahistorical, blurred and shrouded in darkness. Such a situation has had significant consequences. It removes the Pagan past from historiography on the origins of the Polish state and culture, and consequently also from Polish heritage.

\section{Roman Catholic Dominance and National Heritage in Poland}

The case of Poland demonstrates how consistent state policy on managing the past embraces many elements of the memory complex, including national heritage. It does not constitute a separate element in the state policy but a co-product of the government's investment in history. The main institution managing national heritage 
in Poland is the Ministry of Culture and National Heritage. It announces programs for financing cultural activities, which in many cases overlap with the practice of building, preserving, or reinforcing heritage. Other initiatives involving the promotion of heritage are financed and supported by local institutions, though they often follow the direction delineated by the state historical policy.

My analysis of the memory complex in Poland pertains to the short period between 2015 and 2018, when two big programs of financing cultural activities (i.a., concerning the promotion of Polish national heritage) were announced by the Ministry of Culture and National Heritage, providing the funding for hundreds of national and local initiatives. Their objectives followed the state historical policy. Both were related to the anniversaries of two events labeled crucial in the conservative historical policy: namely the Baptism of Poland in $966^{8}$ and the regaining of Polish independence in 1918. The first program, called "Baptism 966" (Chrzest 966) ${ }^{9}$, was designed to finance initiatives promoting the Baptism of Poland as a milestone in the development of national history and identity: the actual beginning of Polish culture. The second, "Independent" (Niepodlegta $)^{10}$, aimed at supporting events celebrating the centennial anniversary of Polish independence. Through providing an opportunity for financing cultural events on the national and local scale, they imposed a model of organizing heritage-related initiatives that were supposed to refer to the values outlined in the programs' premises.

However, the idea of Polishness perceived through the lens of Roman Catholicism has been questioned and has become a subject of debate or of contesting practices (see Zubrzycki 2006), as has the idea of a national heritage built on Christian roots. These contesting practices are more visible on a local scale, in grassroots initiatives, than on the level of the state policy imposing its mainstream pro-Catholic discourse. Thus, bottom-up actions and initiatives give researchers more opportunities to examine alternative ways of creating Polish heritage.

\section{THE RĘKAWKA CELEBRATION IN KRAKÓW: PAGAN HERITAGE IN THE PUBLIC SPHERE}

The aim of the above section of the article was to present the general discourse within which organizations and individuals striving for presenting, preserving, or promoting cultural heritage operate. Importantly, the present part of the text focuses

${ }^{8}$ Interestingly, the idea of the Baptism of Poland as the beginning of the Polish state - though presented in a secularized way - was used in Communist policy, especially in 1966, when huge celebrations of the millennial anniversary of the creation of the Polish state were organized all over Poland. The social perception was not entirely secularized though, and on a grassroots level the Baptism was seen as a religious event. Its historical interpretation - as the beginning of the Polish state - was also absorbed by the Roman Catholic Church, and during Communist rule and in Church policy the event was identified with the origins of the Polish state. It has become simultaneously a symbol of religious renewal and of the start of the actual, Christian history of Poland. For more see Zaremba 2005.

${ }^{9} \mathrm{http}: / /$ chrzest966.pl/, accessed 27.03.2019.

${ }^{10}$ https://niepodlegla.gov.pl/, accessed 27.03.2019. 
on the people who introduce heritage to the public sphere, that is, the local stakeholders, and not on their audiences. I wish to analyze the stances that the organizers of historical reenactments of the Pagan past take toward the dominant role of Roman Catholicism in Poland, and to ascertain whether their strategies in regard to this situation enable them to achieve their goals.

Many grassroots initiatives focusing on the preservation of heritage or the promotion of regional history are undertaken by historical reenactors ${ }^{11}$. In Poland they form a very specific group of people operating within the framework of the state historical policy. Their practices, the events they organize, and their ways of participating in the public sphere are very often directly dependent on certain history fashions in Polish culture (Baraniecka-Olszewska 2018), identity matrixes (Kurczewska 2015), or collective memories (Kwiatkowski 2008) present in social life. As such, they are to some degree dependent on the state historical policy. Some reenactors consciously follow the state historical policy; some operate at its margins; some openly contest it. Reenacting early medieval Pagan cultures in Poland is an example of the latter attitude toward the state historical policy. Events promoting Pagan heritage are usually overlooked in this policy. Thus, as I show below, operating within the confines of a particular historical policy and turning it to advantage in heritage-making requires some skill, and also the ability to cut the coat according to the cloth.

The example I have chosen is the organization of the Traditional Celebration of Rękawka in Kraków, an event which is organized parallel to Roman Catholic celebrations also called Rękawka ${ }^{12}$. It is a historical reenactment of early medieval Pagan Slavic rituals held annually, on the Tuesday after Easter, under Krakus Mound in the Podgórze distric $\mathrm{t}^{13}$. Although the history of the "Traditional Celebration of Rękawka" may only trace back to 2001, when the Podgórze Culture Center decided to organize the event along with the historical reenactment group of the "Krak" Vistulan Warrior Host (Drużyna Wojów Wiślańskich "Krak") ${ }^{14}$, the original Rękawka celebration's history is much longer. It has been organized from at least the sixteenth century on two neighboring hills - Lasota Hill and Krakus Mound - as a Roman Catholic indulgence feast, although there are suppositions that the roots of the celebration lie somewhere in the early Middle Ages and in the Pagan religion. Pagan traces were noticed in the Rękawka celebration by nineteenth-century ethnographers (e.g., Gloger 1903; Gołębiowski 1831; Gonet 1897; Kolberg 1976; Ulanowska 1884) and such an image of the celebration also prevails in related ethnographical accounts dating from the twentieth century (Pisarzak 1978; Seweryn 1961). In the twenty-first century, the concept

${ }^{11}$ It is important to note that historical reenactors also take part in state-organized events or ones prepared by local authorities; however, most historical reenactment events are the outcome of a certain friction between top-down and bottom-up interests.

${ }_{12}$ Within the HERA project I conducted ethnographic fieldwork on Rękawka in 2018. I would like to express my gratitude to Dr. Alicja Soćko-Mucha, who supported me during the research; she collected some of the material presented in this article.

${ }^{13}$ On the history and characteristics of Podgórze district see Niedźwiedź 2017.

${ }^{14}$ Krak (Krakus) was a legendary ruler of Kraków, the founder of the city. 
has found a new form of appropriation, namely historical reenactment. Currently, the Rękawka event consists of two parallel celebrations: a Roman Catholic indulgence feast and a historical reenactment of the Pagan Slavic past, named by its organizers the Traditional Celebration of Rękawka (for further details see: Baraniecka-Olszewska 2016).

The Roman Catholic celebration, held on Lasota Hill in the small medieval Church of St. Benedict, is mainly a religious celebration, reinforcing the Roman Catholic identity of Kraków and also of the Podgórze district ${ }^{15}$. The Roman Catholic heritage - to which this part of the Rękawka event belongs - is the default type of religious heritage in Poland. This kind of heritage is also visible in the public sphere; it is common and rarely contested openly. It is promoted as one of many elements deeply embedded in the memory complex in Poland; officially it is often left in the hands of the Church, which also fulfills the objectives of the state historical policy and runs its own memory policy (Bogumil, Głowacka-Grajper 2019). Such is the case of the Rękawka celebration on Lasota Hill - it is a parish event, organized and supported by the Roman Catholic Church. It has no city patronage, no posters or other kind of advertisement, but nevertheless forms a default basis for local heritage. To use Pasieka's (2015) words, it reflects that which is "normal" and "traditional", and it is regarded as one of Kraków's most important traditions (Oleszkiewicz 2016).

The name and fame of the Rękawka event on Lasota Hill ${ }^{16}$ was taken over by the organizers of the "new" Rękawka, who decided to bring back the original character of the event, namely, the Pagan one. The organizers of this Rękawka have differing religious affiliations. Some are Roman Catholic, some Pagan, some declare themselves to be non-believers. They form a heterogeneous group and their approaches to organizing the event also vary. What they have in common is their appreciation for the local pre-Christian culture and the desire to introduce it to the public. Some people taking part in preparing the Rękawka celebration (here meaning mostly the reenactors who perform during Rękawka) are Pagans themselves and for them introducing Pagan religion to the public sphere, which is dominated by Catholicism, is a crucial task. Another group of the organizers of the event see Paganism as a continuous religion and find it important to present it as a native alternative to Christianity, which through time has become perceived as native for this part of Europe. There is also a group of people who might be called cultural Pagans ${ }^{17}$ - people who feel a certain affinity with Paganism and Pagan culture, though they are not necessarily Pagan themselves (see Simpson 2017, p. 84). They also form the largest group among the

${ }^{15}$ In both cases - the city of Kraków in general and the Podgórze district - Roman Catholic heritage is challenged by Jewish heritage, and these discourses are constantly competing.

${ }^{16}$ For details of the history of Rękawka see Seweryn 1961.

${ }^{17}$ Scott Simpson (2017) uses the term rodzimokulturowcy (Simpson explains it as "Native Culture, following on the model of Native Faith", p. 84) which refers to the particular Pagan faith - rodzimowierstwo (Native Faith), yet I would like to use his idea in order to coin a term describing the people I talked to in the field. I would describe them as cultural Pagans: people convinced about the value of Pagan faith and culture, both in the past as in the present. Importantly, being a cultural Pagan does not prevent a person from being a cultural Roman Catholic and seeing worth in both these religions. 
Rękawka events' organizers, as well as among reenactors participating in the Rękawka event, and as such they constitute the largest group of people I talked to during my research. Both these groups feel uncomfortable operating within Christian-biased models of heritage imposed by the state historical policy and the cultural institutions realizing it. There is, however, a group of Roman Catholic organizers whose aims are different. They want to present the pre-Christian past as a significant historical period, but they are not working to introduce Pagan religious heritage to the public sphere. Although the organizers' agendas vary, they are all accommodated in the event.

Currently, the Traditional Celebration of Rękawka is a reenactment of rituals and events which allegedly belonged to a pre-Christian event. Each year, the Traditional Celebration of Rękawka follows a different script and a new leading theme. Usually the theme refers to the spiritual life of the ancestors. In 2018 it was the Slavic Netherworld and creatures from Slavic demonology as well as Slavic gods appeared below Krakus Mound to interact with visitors. They invited visitors to pass a gate surrounded with skulls and enter the Netherworld, where god Weles and his entourage were waiting for new souls. Playfully, the gods and their assistants tried to prevent the new souls from escaping to the mundane world again. As the reenactors impersonating gods expected food offerings, they told the visitors that their fate was already sealed, and no one can leave the Netherworld. In addition, a few performances related to other local Slavic beliefs were presented at the Rękawka celebration; the performances emphasized the meaning of the Pagan culture for regional history and identity and explained the actual pre-Christian provenance of local legends and stories.

Yet the Traditional Celebration of Rękawka does include a number of fixed elements. A fire is lit (quite often by an actual Pagan priest) at the top of the Krakus Mound in combination with the placing of food offerings. By some Rękawka participants, this part is identified with an actual Pagan ritual and for some holds a religious meaning. Other parts of Rękawka, although related to the past spiritual life are perceived as reenacted elements of early medieval religion. There is a divination to inquire about the prosperity of the city of Kraków: a priest hides behind a huge loaf of bread and if the spectators cannot see him there, good fortune is foretold for the city. In a reconstructed Pagan temple with a figure of the god Swiatowid, reenactors tell the spectators about the Pagan religion. An interesting example of interpreting past rituals is a race between warriors in full armor. The race is a product of the reenactors' imagination of the games accompanying various religious rituals in the pre-Christian period, for instance, those at the burial of a famous warrior. Each year, the Rękawka event ends with a staged burial, usually in the form of a cremation rite.

In the Rękawka scenario, there are also elements characteristic of all early medieval reenactment events. Visitors can wander through a warriors' encampment, see reconstructed armor and weapons, and listen to the reenactors' stories about the past they have recreated. They can also buy craft items such as pottery, jewelry, or textiles made according to early medieval methods. However, the most popular event is a staged battle between tribes which could have been fighting with each other, although there are no sources to confirm that they in fact did so. 


\section{CHALLENGING THE ROMAN CATHOLIC VISION OF POLISH HISTORY}

In accord with the intentions of the cultural Pagans, the Rękawka event should be one of the mediums for promoting an alternative to the dominant Christian interpretation of Polish history. It is, however, not solely an attempt to introduce Pagan history to the memory complex in Poland, nor the only way of entering the discussion over the dominant Roman Catholic-biased project of Polish national identity. Importantly, contemporary Paganism in Poland in its particular realizations also offers a political ideology, which is often related to right-wing nationalism (Filip 2011; Gajda 2009; Kośnik 2015). The engagement of some Polish Pagans (mostly those with a connection to a Native Faith) with history and politics is often identified with nationalism, although the attitudes Pagans display toward the past, to national identity, or to political ideology are very diverse. Nevertheless, as far as the present analysis is concerned, it is crucial to consider the fact that Pagans have constructed their own visions of national identity. Again, its versions and variants vary and cannot be perceived as harmonious, but en masse they constitute an alternative to the Roman Catholic vision of Polish identity and thus imply a different understanding of history (Kośnik 2018; see also Grott 2006). Although the organizers of the Traditional Celebration of Rękawka can hardly be described as followers of a rightist Pagan vision of Polish identity, the mere idea of challenging the dominant Roman Catholic perspective on Polish history and identity within it is visible in their efforts to build a Pagan heritage in Poland. Moreover, the event reflects the place contemporary Pagans hold in Polish politics. Paganism thus entails not only religious attitudes, but also ideological ones; it proposes certain historiographic solutions.

Although the Traditional Celebration of Rękawka cannot be unequivocally described as a Pagan religious event, it can, however, be analyzed in terms of creating Pagan heritage, one which exceeds Kraków's local heritage and relates also to the pre-Christian past of the territory which today constitutes Poland. As mentioned in the first part of the article, the state-promoted vision of Polish history is limited to the Christian period; consequently it creates the image of Poland as a strong Christian state emerging out of a realm of folk tales and legend ${ }^{18}$. The aim of the Rękawka organizers is to challenge the vision of Christianity as an exclusive culture-making factor in Poland's - and thus Kraków's - past and to explain to audiences the area's historical Pagan culture, which they regard as autonomous, valuable, and well-developed, and as laying the foundations for Kraków's culture in the present.

Interestingly, the Rękawka event's organizers see their own efforts as only partially successful; the perception of success is very much dependent on how radically a given person judges the dominance of the Roman Catholic Church in Poland. The more critical the organizer is in this respect, the more skeptical their thoughts on the Rękawka event's success become. In general, however, the organizers are proud of the

${ }^{18}$ Such is also the narrative behind the permanent exhibition in the Podgórze Museum, which was opened in April 2018. 
popularity of their event, and feel happy that thousands of visitors come to participate in it each year. They also express satisfaction with the fact that the celebration is currently part of Kraków's cultural landscape and has a fixed place in the calendar, albeit together with the Roman Catholic Rękawka celebration. Moreover, the event is supported by the municipal and district authorities. It is advertised all over the city, takes place under the patronage of Kraków's authorities, and has been associated with Kraków's "traditional" Rękawka celebration. Therefore, it could be argued that the authorities openly promote Pagan heritage and that the dominant Roman Catholic vision of national heritage is challenged not only by grassroots initiatives, but also by the municipal authorities of Kraków.

Such a conclusion would, however, be a huge overstatement and the organizers of the Traditional Celebration of Rękawka are aware of it. The city supports the organization of the event mainly because, in the public's perception, the "new" and "old" Rękawka celebrations have merged into one. It is presently identified with the famous ethnographic triad, and local authorities see it as promoting the city's folklore. They may appreciate its colorfulness but not the actual historical culture on which the event is based and which is reconstructed by historical reenactors. Some of the organizers of the Traditional Celebration of Rękawka consider this to be a failure in building Pagan heritage. They are aware that they have not managed to introduce Pagan elements to the Polish national heritage. They are granted access to the public sphere merely to perform what is perceived as Kraków's folklore. Other organizers are, nevertheless, satisfied with the results. Some state that even this opportunity to inform people about pre-Christian culture is valuable. However, for those who strive for recognition of the local Pagan past as a historical, autonomous culture which laid the basis for the development of the city of Kraków and of Paganism as an actual religion (in modern times as well), the present state of affairs is hugely unsatisfactory. This kind of failure, in my opinion, is a result of the state's policy on the Polish past, which basically ignores the pre-Christian period.

\section{CONCLUSIONS}

As far as events promoting Slavic pre-Christian culture in Poland are concerned, the Traditional Celebration of Rękawka is quite exceptional. Drawing on the tradition of the Rękawka celebration as such and the celebration's rootedness in Kraków's history and identity, it attracts a different type of audience than all other early medieval historical reenactments. Visitors coming to the Rękawka event are interested not only in the reenacted past, in buying replicas of jewelry or pottery from the period and witnessing a restaged battle, but also in the customs of Kraków. Thus, many of them perceive the Traditional Celebration of Rękawka to be combined with the Rękawka event in St. Benedict's Church in Kraków, which the residents of the city have known their whole lives. They see the new part as an extension of the older one - as part of Kraków's heritage. Although the Traditional Celebration of Rękawka is recognized as part of Kraków's heritage both by visitors and by the municipal and district authori- 
ties supporting the event, it is not regarded as Pagan heritage, as at least some of the organizers would wish it to be. It is perceived rather as an entertaining performance of the legendary past, more a staging of Kraków's folklore than a reenactment based on the city's actual history or an evocation of pre-Christian religious values.

In my opinion, a certain misinterpretation of the intentions of at least some of the organizers of the Traditional Celebration of Rękawka stems from the state historical policy which - as I have argued throughout this article - also determines the perception of Polish national heritage by its recipients. Although this influence is not always direct, it permeates the whole Polish memory complex. The discourses on heritage and history consequently affect the existence of non-Roman Catholic religious heritage in the public sphere. The current state historical policy supports a hierarchy of religious pluralism and reinforces the normative character of Roman Catholicism. The Roman Catholic heritage has therefore become a sort of default Polish religious heritage and an inherent element of Polish national heritage. At present, to contest it means not only to struggle with the state historical policy, but also to make an attempt to reverse the hierarchy of religions in Poland.

I consider that since Paganism as such is not recognized in the public sphere as an actual, serious religion, and is perceived almost exclusively through the lens of the dominant Roman Catholic creed (see also Simpson 2017, pp. 69-70), Pagan heritage is not acknowledged as part of the national religious heritage. To achieve this goal, its custodians would need to challenge the almost mono-religious vision of national heritage in Poland. Challenging it, however, is not easy, precisely because of the very strong ties between the policies of national history, memory, identity, and Roman Catholicism described in the first part of the article. Due to the state-level dominance of Roman Catholicism and its default presence in all these spheres, cracks in the picture can only be made by groups with strong claims to heritage in Poland (e.g., Jewish groups, see: Kajder this volume) or on a small scale, at the local level, where grassroots initiatives can find the necessary support.

\section{LITERATURE}

Astor Avi, Burchardt Marian, Griera Mar 2017, The politics of religious heritage: Framing claims to religion as culture in Spain, Journal for the Scientific Study of Religion, vol. 56, no. 1, pp. 126-142.

B a raniecka-Olszewska Kamila 2016, Re-enacting historical Slavic rites in contemporary Poland: The Rękawka fair in Cracow, Anthropological Journal of European Cultures, vol. 25, no. 1, pp. 118-135.

B a raniecka-Olszewska Kamila 2018, Reko-rekonesans: praktyka autentyczności. Antropologiczne studium odtwórstwa drugiej wojny światowej w Polsce, Kęty, Wydawnictwo Marek Derewiecki.

Bogumił Zuzanna, Głowacka-Grajper Małgorzata 2019, Milieux de mémoire in late Modernity: Local communities, religion and historical politics, Peter Lang, Berlin.

D e C e s a ri Ch i a r a 2013, Thinking through heritage regimes, [in:] R.F. Bendix, A. Eggert, A. Peselmann (eds.), Heritage regimes and the state, Universitätsverlag Göttingen, Göttingen, pp. 399-413. 
Colem a n Simon, B ow man Marion 2018, Religion in cathedrals: pilgrimage, heritage, adjacency, and the politics of replication in Northern Europe, Religion, vol. 49, no. 1, pp. 1-23.

Filip Mariusz 2011, Polityka tożsamości we wspólnotach neopogańskich. Przykład Zakonu Zadrugi „Północny Wilk”, [in:] W. Dohnal, A. Posern-Zieliński (eds.), Antropologia i polityka. Szkice z badań nad kulturowymi wymiarami władzy, Komitet Nauk Etnologicznych PAN, Instytut Archeologii i Etnologii PAN, Warszawa, pp. 175-188.

Gaj d a A g ni es zka 2009, Co zostało po Stachniuku? Przykład nacjonalistycznego stowarzyszenia „Zadruga”, Państwo i Społeczeństwo, no 9, pp. 79-92.

Di Giovine Michael A. 2015, When popular religion becomes elite heritage: Tensions and transformations at the shrine of St. Padre Pio of Pietrelcina, [in:] M. Robinson, H. Silverman (eds.), Encounters with popular pasts. Cultural heritage and popular culture, Springer, Berlin, pp. 31-47.

Gloge r Zyg m u n t 1903, Encyklopedia staropolska ilustrowana, vol. 4, Druk P. Laskauer, Warszawa. G ołęb i o w ski Łukas z 1831, Gry i zabawy różnych stanów w kraju calym lub niektórych tylko prowincyach, N. Glüksberg, Warszawa.

G o n et S zy mo n 1897, Rękawka i skały Twardowskiego w Podgórzu, Lud, vol. 3, no. 1, pp. 76-7.

G ó r e w i c z I g o r 2008, Od indyferyzmu do neopogaństwa. Oceny „warunków zastanych” w Polsce przez Romana Dmowskiego i Jana Stachniuka w świetle ich stosunku do religii katolickiej, Państwo iSpołeczeństwo, no. 8, pp. 141-165.

Groot de Jerome 2009, Consuming history. Historians and heritage in contemporary popular culture, Routledge, USA-Canada.

Grot t B og u m ił 2006, Nacjonalizm czy nacjonalizmy?, Nomos, Kraków.

Is nart Cyril 2008, Making saints and performing locality as heritagization?: An ethnography of local holiness and village identity in the French and Italian Alps, Journal of Mediterranean Studies, vol. 18, no. 1, pp. 79-91.

Kolberg O ska r 1976, Dzieła wszystkie, vol. 5: Krakowskie, Part 1, PTL, Poznań-Wrocław.

Korzen iewski B artos z 2008, Wprowadzenie. Polityka historyczna-propozycje definicji i spory wokół jej zakresu w polskim i niemieckim dyskursie naukowym, [in:] B. Korzeniewski (ed.), Narodowe i europejskie aspekty polityki historycznej, Instytut Zachodni, Poznań, pp. 7-28.

Kośnik Kon rad 2015, Tożsamość współczesnych rodzimowierców słowiańskich. Studium psychologiczne aktywności internetowej rodzimowierców w Polsce, Przegląd Religioznawczy, no. 3, pp. 119-134.

Kośn i k Kon r a d 2018, Internetowe narracje historyczne a słowiańska tożsamość Polaków. Prolegomena teoretyczna, Sensus Histioriae, vol. 30, pp. 57-68.

$\mathrm{Ku}$ b i k J a 1 1994, The power of symbols against the symbols of Power. The rise of Solidarity and the fall of state Socialism in Poland, The Pennsylvania State University Press, University Park, Pennsylvania.

Kurczewska Joanna 2015, „Dwa spotkania międzykulturowe - przedstawienia i konteksty”, Górnoślaskie Studia Socjologiczne. Seria Nowa, no. 6, pp. 28-55.

Kw i t kow sk i P i o tr T. 2008, Pamięć zbiorowa społeczeństwa polskiego w okresie transformacji, Wydawnictwo Naukowe Scholar, Warszawa.

Łu c ze w s ki M i ch ał 2017, Kapitał moralny. Polityki historyczne w późnej nowoczesności, Ośrodek Myśli Politycznej, Kraków.

McD on ald Sh ar o n 2013, Memorylands. Heritage and identity in Europe today, Routledge London-New York.

Ni ed źwiedź A n n a 2007, Krakowskie Podgórze - dziedzictwo odkrywane, [in:] Andrzej Stawarz (ed.), Miasto po obu brzegach rzeki. Różne oblicza kultury, Muzeum Historyczne m.st. Warszawy, Muzeum Niepodległości, Warszawa, pp. 187-200.

Oleszkiewicz Małg or zat a 2016, Storage of rituals. The traces of the Emmaus and the Rękawka church fairs in the Seweryn Udziela Ethnographic Museum in Kraków as the examples of the intangible heritage in museums, [in:] M. Kwiecińska (ed.), Intangible heritage of the city. Musealization, preservation, education, The Historical Museum of the City of Kraków, Kraków, pp. 153-166.

P a s i e ka Agni es zk a 2015, Hierarchy and Pluralism: Living Religious Difference in Catholic Poland, Palgrave Macmillan, United States. 
P i s a r z a k M a ri a n 1978, Obrzędowość wiosenna w dawnych wiekach w związku z recepcją „święconego" w Polsce, Lud, vol. 62, no. 1, pp. 53-74.

Porter-Szücs B rian 2011, Faith and fatherland. Catholicism, modernity, and Poland, Oxford University Press, New York.

S a muel Raphael 2012 [1994], Theaters of memory. Past and present in contemporary culture, Verso, London-Brooklyn NY.

S eweryn Ta de us z 1961, Tradycje i zwyczaje krakowskie, Wydawnictwo Artystyczno-Graficzne, Kraków.

S i m p s o n S c o tt 2017, Only the Slavic Gods: Nativeness in Polish rodzimowierstwo, [in:] K. Rountree (ed.), Cosmopolitanism, nationalism, and modern Paganism, Palgrave Macmillan. New York, pp. 65-86.

S mith Laurajane 2006, The uses of heritage, Routledge, London-New York.

Tr a b a R o b e r t 2010, Polityka wobec historii: kontrowersje i perspektywy, Teksty Drugie, nos. 1-2, pp. 300-319.

Tunbridge John E., A shworth Gregory J. 1996, Dissonant heritage: The management of the past as a resource in conflict, John Wiley, Chichester.

Ulanowska Stefani a 1884, Co to jest Rękawka?, s.n., Kraków.

Wolff-Pow ęska An n a 2007, Polskie spory o historię i pamięć. Polityka historyczna, Przegląd Zachodni, no. 1, pp. 3-45.

Z a r e m b a Marcin 2005, Komunizm, legitymizacja, nacjonalizm. Nacjonalistyczna legitymizacja władzy komunistycznej w Polsce, Instytut Studiów Politycznych PAN, Warszawa.

Zubrzycki Geneviève 2006, The crosses of Auschwitz. Nationalism and religion in post-Communist Poland, The University of Chicago Press, Chicago-London.

\section{KAMILA BARANIECKA-OLSZEWSKA}

\section{THE STATE HISTORICAL POLICY AND THE DEFAULT RELIGIOUS HERITAGE IN POLAND: ON INTRODUCING PAGAN HERITAGE TO THE PUBLIC SPHERE IN KRAKÓW}

Keywords: Paganism, heritage, historical policy, Roman Catholicism, historical reenactment, Kraków, Poland

This article discusses the role of the state historical policy in constructing national heritage in Poland. The author focuses mostly on the dominant place Roman Catholicism occupies in the Polish memory complex and in Roman-Catholic-related national identity projects, since these also affect the process of construing national heritage. Applying Pasieka's notion of hierarchical religious pluralism, the author examines the construction of religious heritage according to the objectives of the contemporary conservative state historical policy. Assuming that Roman Catholicism constitutes the default element in the national heritage in Poland, the author examines how an alternative vision of religious heritage is created and what role minority religions play in the heritage-making processes in Poland. The case study is the Rękawka Celebration in Kraków - a historical reenactment of early medieval Slavic Pagan rites.

Author's Address:

Dr hab. Prof. PAN Kamila Baraniecka-Olszewska

Institute of Archaeology and Ethnology PAS

Al. Solidarności 105, 00-140 Warszawa

E-mail: kamila.baraniecka@gmail.com

ORCID: https://orcid.org/0000-0002-9560-3167 